\title{
The surprising effects of transparency on the EU legislative process*
}

\author{
Stéphanie Novak \\ Hertie School of Governance
}

\begin{abstract}
Contents: I. Introduction.-II. Explanations of transparency of the EU legislative process. 1. Acknowledgement of a legal progress. 2. The empirical approach to transparency: Implementation and effects of the rules. 2.1. The realist conventional wisdom. 2.2. The organizedhypocrisy explanation. 2.3. "Conversion" of transparency rules. - III. Data and methodology.-IV. Results. 1. The implementation of transparency rules in the Council of the European Union. 1.1. Publicity of written documents. 1.2. Publicity of sessions. 1.3. Publication of votes. 2. The codecision. - V. Discussion. 1. The limits of the realist common wisdom. 2. Publicity as a Potemkin Village? A critique of the organized-hypocrisy theory. - VI. Conclusion. - VII. Bibliography.
\end{abstract}

\begin{abstract}
Since the 1990s, several rules have been adopted to increase the transparency of the EU legislative process. This paper explores their effects on the accountability of the actors on the basis of 70 semi-structured interviews and document analysis. The empirical study shows a relative failure of transparency rules, partly because the actors benefit of a high degree of discretion in the enforcement of rules. However, the paper argues that more than evading the rules, EU decision-makers tend to implement them strategically, that is, to redirect them toward more beneficial effects.
\end{abstract}

Keywords: Transparency, EU institutions, decision-making process.

Resumen: Desde la década de los 90, se han adoptado diversas normas en la Unión Europea para aumentar la transparencia del proceso legislativo. Este artículo explora los efectos de dichas normas sobre la rendición de cuentas de los actores implicados. El estudio empírico, basado en 70 entrevistas semiestructuradas y en el análisis de documentos, muestra un relativo fracaso de las normas de transparencia, en parte debido al alto grado de discreción que gozan los actores europeos en la implementación de las mismas. El artículo argumenta que, en vez de evadir las reglas sobre transparencia, los actores del proceso de decisión tienden a hacer un uso estratégico de las mismas, dirigiéndolas hacia efectos más beneficiosos.

Palabras clave: Transparencia, instituciones europeas, proceso de adopción de decisiones.

* Recibido el 15 de abril de 2014, aceptado el 9 de junio de 2014. 


\section{Introduction}

Since the beginning of the 1990s, the European Union has adopted a number of measures to make information on the legislative process and more precisely, the positions taken by member states, more public. Due to pressures from the European Parliament (EP), the Council of the European Union has progressively begun to publicize more information, and in particular, its voting records. The Council has a reputation of being an opaque institution. But have these measures actually increased the transparency of the EU legislature? Some studies would suggest that they have a contradictory effect in making legistators hide their decision-making processes. This paper investigates the impact of transparency rules on the practice of the EU legislative institutions. "Transparency" has become a buzzword of late, with more and more organizations forced to show that they are, in fact, transparent. This evolution is due to the fact that transparency, legitimacy and accountability seem to be necessarily interrelated, even if these links are more problematic than is often admitted". While organizations cannot publicly say "no" to transparency, it is often the case that the actors within them do not necessarily consider transparency desirable or even compatible with their practices. However, the relationship between the EU official rules of transparency and the actors' decisional practices has not been theorized in depth partly because such research raises methodological issues. The paper proposes to distinguish four possible effects of introducing transparency into the EU legislative process.

Firstly, the legislative actors might comply with the transparency rules. In such case, transparency rules increase public information on the positions of the legislative actors and serve to increase their accountability. Secondly, the legislative actors might evade the transparency rules. In such situation, the actual effect of transparency rules is opposite to their official goal because publicity leads the legislative actors to withdraw behind closed doors when they have to act and make decisions. Given the notoriety of the Council's diplomatic practices, this argument sounds like a kind of "realist conventional wisdom". Thirdly, the legislative actors might ignore the transparency rules. In such situation, transparency rules remain decoupled from the legislative actors' practices and therefore do not increase public information. This explanation draws on the organized-hypocrisy theory. According to Brunsson, organized hypocrisy arises when an organization adopts an official stance to gain public legitimacy while its acts and decisions remain disconnected from this official

1 CURTIN, D. and MEIJER, A., "Does transparency strengthen legitimacy?", Information polity 2006, Vol. 11, No. 2, pp. 109-122; NAURIN, D., "Transparency, Publicity, Accountability - The missing links“, Swiss Political Science Review, 2006, Vol. 12, No. 3, pp. 90-98. 
stance. Fourthly, the legislative actors might convert $^{2}$ the transparency rules, that is they implement the rules but they exploit their ambiguities to redirect them toward more favorable effects. In such situation, the rules do not guarantee that the actors' stances behind closed doors are made public.

On the basis of an empirical study, this paper will attempt to test these four explanations. It argues that transparency rules mostly fail to guarantee the accountability of legislative actors. Nonetheless, neither the organizedhypocrisy theory nor the realist conventional wisdom fully account for the effects of transparency rules because they underestimate the complexity of rule implementation. This paper claims that the actors strategically implement the rules by converting them to new goals that are more beneficial to them. The main implication of this finding is that transparency rules can fail to increase accountability. In this context, this research is in line with a body of recent studies investigating the links between transparency and accountability ${ }^{3}$.

The first section reviews explanations of transparency in EU institutions. The second section presents the methodology and data. The third section analyzes the implementation of the transparency rules and their effects on the legislative process of the European Union. The fourth section discusses the relative failure of transparency rules and argues that more than evading or ignoring the transparency rules, the actors tend to convert them.

\section{Explanations of transparency of the EU legislative process}

This paper defines transparency as the availability of information about an actor allowing other actors to monitor her actions and decisions ${ }^{4}$. Most existing studies of transparency in EU institutions focus on its evolution as a legal concept while empirical studies of the implementation of transparency rules are rather rare.

\section{Acknowledgement of a legal progress}

Since the beginning of the 1990s, the evolution of transparency rules in EU institutions has been dramatic. The rejection of the Maastricht Treaty by

2 MAHONEY, J. and THELEN, K. (Eds.), Explaining Institutional Change: Ambiguity, Agency, and Power, Cambridge University Press, New York, 2010.

3 HOOD, C., "Accountability and Transparency: Siamese Twins, Matching Parts, Awkward Couple?" West European Politics, 2010, Vol. 33, No. 5, pp. 989-1009; TAN, Y., «Transparency Without Democracy: The Unexpected Effects of China's Environmental Disclosure Policy», Governance, 2014, Vol. 27, No. 1, pp. 37-62.

4 MEIJER, A., "Understanding the Complex Dynamics of Transparency", Public Administration Review 2013, Vol. 73, No. 3, pp. 429-439. 
the Danish people partly triggered this evolution, while the development of the Internet further accelerated this institutional change. The legal provisions mandating transparency are mainly formulated in Regulation 1049/2001 and in Article 15 of the Treaty on the Functioning of the European Union ${ }^{5}$. Scholars have focused on the origins ${ }^{6}$ and the evolution of transparency rules ${ }^{7}$. The most dramatic evolution has taken place in the Council of the European Union. Under pressures from the EP, four member states (Netherlands, Sweden, Denmark and Austria), and civil society, the Council has been compelled to deliver more and more information on its activities ${ }^{8}$. Since December 1993, votes must be made public. Since 1999, a public register gathers all "non-sensitive" documents. Since 2006, the Council meets in public when deliberating or voting on legislative acts that it must codecide with the EP. Public sessions are broadcast by videostreaming on the Internet. Furthermore, existing studies acknowledge that an "active" policy of transparency has replaced "passive" transparency": while transparency initially meant the right of citizens to request documents, the Council must now publish information on its website. Still, scholars have also pointed out the shortcomings of the transparency rules when it comes to the Council's executive role and EU security policies ${ }^{10}$.

\section{The empirical approach to transparency: Implementation and effects of the rules}

There has been little empirical research on the implementation and effects of transparency rules on the European legislative process. This shortcoming is partly due to methodological hurdles, since such investigation requires

5 Treaty on the Functioning of the European Union, Consolidated Version, Official Journal of the European Union, 2012, C326/47.

6 BJURULF, B. and ELGSTRÖM, O., "Negotiating Transparency: The Role of Institutions", Journal of Common Market Studies, Vol. 42, No. 2, 2004, pp. 249-269.

7 DECKMYN, V. and THOMSON, I., Openness and Transparency in the European Union, EIPA, Maastricht, 1998; DECKMYN, V. (Ed.), Increasing Transparency in the European Union? EIPA, Maastricht, 2002; DE LEEUW, M.E., "Openness in the Legislative Process in the European Union" European Law Review, 2007, Vol. 32, No. 3, pp. 295-318; HILLEBRANDT, M. Z., CURTIN, D. and MEIJER, A., "Transparency in the EU Council of Ministers: An Institutional Analysis", European Law Journal, 2014, Vol. 20, No.1, pp. 1-20.

8 BRUNMAYR, H., "The Council's Policy on Transparency", in DECKMYN, V. and THOMSON, I., Openness and Transparency in the European Union, EIPA, Maastricht, 1998, pp. 69-73.

${ }^{9}$ CURTIN, D., "Transparency, Audiences and the Evolving Role of the EU Council of Ministers", in FOSSUM, J.E. and. SCHLESINGER, P.R., The European Union and the Public Sphere. A communicative space in the making, Routledge, 2007, pp. 246-258.

${ }^{10}$ Ibid.; CURTIN, D., “Top Secret Europe”, Inaugural Lecture, University of Amsterdam, 2011. 
comparing what happens behind closed doors with the outcomes of public sessions ${ }^{11}$. A few recent studies of diverse institutional settings have overcome these hurdles ${ }^{12}$. Like these studies, this paper assumes that analysis of transparency rules should be complemented with research of their effects because, like any policy, transparency policies can fail. In the case of the EU legislative process, we still have to assess whether transparency rules have achieved their main objective (defined in Article 15 of the TFEU, 2012): to inform citizens of the positions taken by their representatives in the legislative process.

As mentioned in the Introduction, this paper proposes to distinguish four possible effects of introducing transparency into the EU legislative process. These effects are summarized in the table below.

Effects of transparency on the information made public. A typology

\begin{tabular}{|l|l|l|l|l|}
\hline \multicolumn{1}{|c|}{ Explanation } & \multicolumn{1}{|c|}{$\begin{array}{c}\text { Legalistic } \\
\text { Interpretation }\end{array}$} & $\begin{array}{c}\text { Realist Conventional } \\
\text { Wisdom }\end{array}$ & Organized Hypocrisy & \multicolumn{1}{c|}{ "Conversion" of TR. } \\
\hline $\begin{array}{l}\text { Type of rule } \\
\text { implementation. }\end{array}$ & $\begin{array}{l}\text { The actors } \\
\text { comply } \text { with TR. }\end{array}$ & $\begin{array}{l}\text { The actors } \\
\text { evade TR. }\end{array}$ & $\begin{array}{l}\text { The actors } \\
\text { ignore TR. }\end{array}$ & $\begin{array}{l}\text { The actors } \\
\text { convert TR. }\end{array}$ \\
\hline $\begin{array}{l}\text { Type of effect } \\
\text { on public } \\
\text { information. }\end{array}$ & $\begin{array}{l}\text { Positive effect: } \\
\text { TR do } \\
\text { increase public } \\
\text { information } \\
\text { on the actors' } \\
\text { positions. }\end{array}$ & $\begin{array}{l}\text { Counterproductive } \\
\text { effect: } \\
\text { The public believes } \\
\text { that it can monitor } \\
\text { the process while } \\
\text { actors manage to hide } \\
\text { their positions. }\end{array}$ & $\begin{array}{l}\text { No effect: } \\
\text { The public believes } \\
\text { that it can monitor } \\
\text { the process while TR } \\
\text { are decoupled from } \\
\text { actors' acts. TR do } \\
\text { not increase public } \\
\text { information. }\end{array}$ & $\begin{array}{l}\text { Ambiguous effect: } \\
\text { The public believes } \\
\text { that actors are } \\
\text { subjected to TR while } \\
\text { they actually exploit } \\
\text { their ambiguities in } \\
\text { ways that are more } \\
\text { beneficial to them (eg: } \\
\text { publish a vote that does } \\
\text { not reflect their stance } \\
\text { behind closed doors). }\end{array}$ \\
\hline
\end{tabular}

TR = Transparency Rules.

Transparency rules achieve their official objective when the legislative actors comply with the rules. In such case, empirical investigation should show that the positions taken by the legislative actors are made more public. However, transparency rules might have unexpected effects. Let us consider three other possible effects.

11 GOSSERIES, A., "Transparency and Democracy”, Swiss Political Science Review, 2006, Vol. 12, No. 3, pp. 83-90.

12 NAURIN, D., Deliberation Behind Closed Doors: Transparency and Lobbying in the European Union, ECPR Press, Colchester, 2007; MEADE, E. and STASAVAGE, D., "Two Effects of Transparency on the Quality of Deliberation", Swiss Political Science Review, 2006, Vol. 12, No. 3, pp. 123-133; TAN, Y., op. cit., note 3. 


\subsection{THE REALIST CONVENTIONAL WISDOM}

Firstly, the legislative actors might evade the transparency rules. Studies of the Council sometimes point to the fact that publicity leads actors to withdraw being closed doors. According to Fiona Hayes: "[t]he nagging feeling persists that the transparency provisions, far from shining a spotlight on decision-making in the Council, have instead had the effect of moving the real negotiations out of the range of the cameras and microphones"13. In his study of journalists' access to the Council, Laursen also refers to this phenomenon ${ }^{14}$. One can say that this argument has attained the status of a conventional wisdom ${ }^{15}$. However, we lack empirical research on this issue. Furthermore, supporters of this realist conventional wisdom usually refer to the Council. Yet most legislation is currently codecided by the Council and the EP. It is necessary to test this conventional account by taking into account the entire legislative process and not only the activities of the Council. Given, also, that EP sessions are public, one might expect that the increased power of the EP has triggered better and wider information on the legislative process.

\subsection{THE ORGANIZED-HYPOCRISY EXPLANATION}

Secondly, the legislative actors might ignore the transparency rules. To our knowledge, existing studies have not considered the possibility of a decoupling ${ }^{16}$ of transparency norms and actors' acts and decisions. This type of explanation differs from the realist conventional wisdom because the former assumes a parallelism between official norms and acts and decisions:

13 HAYES-RENSHAW, F., "The Council of Ministers", in PETERSON, J. and SHACKLETON, M., The Institutions of the European Union, Oxford University Press, Oxford, 2012, pp. 68-95; p. 90 quoted by HUBER, K. and SHACKLETON, M., "Codecision: A Practitioner's View From Inside the Parliament", Journal of European Public Policy, 2013, Vol. 20, No. 7, pp. 1040-1055; see also BEST, E., "Transparency and European Governance: Clearly not a Simple Matter", in DECKMYN, V., Increasing Transparency in the European Union?, EIPA, Maastricht, 2002, pp. 91-117; STASAVAGE, D., "Does Transparency Make a Difference? The Example of the European Council of Ministers", Working Paper. London School of Economics, 2005, available at: http://as.nyu.edu/docs/IO/5395/transparency.pdf (last accessed: 1 April 2014).

${ }^{14}$ LAURSEN, B., "Transparency in the Council of the European Union: Why journalists don't get the full picture", Journalism, 2012, Vol. 14, No. 6, pp. 771-789.

15 DAVIS, J., "Access to and Transmission of Information: Position of the Media", in DECKMYN, V. and THOMSON, I., Openness and Transparency in the European Union, EIPA, Maastricht, 1998, p. 126; WESTLAKE, M., "Maastricht, Edinburgh, Amsterdam: The 'End of the Beginning", in DECKMYN, V. and THOMSON, I., Openness and Transparency in the European Union, EIPA, Maastricht, 1998, pp. 142-143.

16 MEYER, J.W. and ROWAN, B., "Institutionalized Organizations: Formal Structure As Myth and Ceremony", American Journal of Sociology, 1977, Vol. 83, pp. 340-363. 
that is, it assumes transparency norms have no effect on the acts and decisions of the actors. The realist conventional wisdom, on the other hand, assumes that publicity has an influence on actors' behaviour: it pushes them to withdraw behind closed doors. The suspicion of a decoupling between the official rules of transparency and actors' practices emerged from the start of the transparency policy. For instance, in 1994, John Carvel, a journalist from The Guardian, sent a complaint to the European Court of Justice because the General Secretariat of the Council had not granted him access to some documents. He explained a few years later:

In fact what was happening was that a substantial majority of Member States took the view that any document revealing a specific national point of view should automatically be withheld. Instead of examining such material on a case-by-case basis to see what might be disclosed, they were effectively inventing a new category of document to which access MUST not be granted. (...) In speech after speech, the national leaders went banging on about the virtues of transparency, but they were subverting the one initiative which might have opened a tiny window on the process of secret legislation. I thought this was hypocritical. And that is why I took the trouble to go to the European Court ${ }^{17}$.

The paper will ask whether the transparency of the EU legislative process can be considered a case of "organized hypocrisy." Situations of organized hypocrisy emerge when an organization adopts official norms to gain public legitimacy even as actors within those organizations follow other rules when they act and decide because they aim primarily at efficiency. This concept was forged by Nils Brunsson ${ }^{18}$ and was first applied by sociologists of organizations before inspiring international relations scholars ${ }^{19}$. However, the concept has not been applied to the study of transparency policies. Since EU institutions are torn between external pressures toward more transparency and the search for efficiency, the organized-hypocrisy theory is especially relevant in analyzing the implementation and the effects of transparency norms.

17 CARVEL, J., "Request for Documents of the Council: An Account of the Guardian Case", in DECKMYN, V. and THOMSON, I., Openness and Transparency in the European Union, EIPA, Maastricht, 1998, p. 60

18 BRUNSSON, N., The Organization of Hypocrisy: Talks, Decisions and Actions in Organizations ( ${ }^{\text {nd }}$ Ed.), Copenhagen Business School Press, Copenhagen, 2006.

19 KRASNER, S.D. Sovereignty: organized hypocrisy, Princeton University Press, Princeton, 1999; LIPSON, M., "Peacekeeping: Organized Hypocrisy?", European Journal of International Relations, 2007, Vol. 13, No. 1, pp. 5-34; WEAVER, C., Hypocrisy Trap: The World Bank and the Poverty of Reform, Princeton University Press, Princeton, 2008; BUKOVANSKY, M., "Institutionalized Hypocrisy and the Politics of Agricultural Trade", in ABDELAL, R. and ITHACA, A., Constructing the International Economy, Cornell University Press, 2010. 


\section{3. "CONVERSION" OF TRANSPARENCY RULES}

Lastly, the legislative actors might convert the transparency rules. They implement the rules but exploit their ambiguities to redirect them toward more beneficial effects. In such situation, the rules have ambiguous effects on public information because they do not guarantee that the public stances of the legislative actors reflect the positions they took behind closed doors. This explanation draws upon a typology proposed by Mahoney and Thelen $^{20}$ to distinguish sources of institutional change. A possible source is the "conversion" of rules, which is likely to occur when the actors benefit of a high level of discretion in the enforcement of rules but have weak veto possibilities. To our knowledge, studies of transparency have not theorized the possibility that the actors convert transparency rules to their own advantage even if in principle, they should be subjected to the rules.

Empirical investigation shows that transparency rules relatively fail to guarantee better public information. However, neither the organizedhypocrisy theory nor the realist conventional wisdom fully explain the effects of transparency rules. The concept of "rule conversion" helps to refine our understanding of the effects of transparency.

\section{Data and Methodology}

The empirical research relies on three types of data.

It first relies on the legal texts on transparency in EU institutions: Regulation n. ${ }^{\circ}$ 1049/2001; Article 16.8 of the TEU ${ }^{21}$ and Article 15 of the $\mathrm{TFEU}^{22}$; the Rules of Procedure of the Council ${ }^{23}$ and of the $\mathrm{EP}^{24}$.

Secondly, it uses documents on the legislative process published by the Council and the EP: Council minutes; the agendas of Council meetings and those of its preparatory bodies (Committee of Permanent Representatives (Coreper) Part 1 and Part 2; Special Committee for Agriculture (SCA)); Council sessions publicly broadcast by videostreaming on the Council website; and the EP Legislative Observatory ${ }^{25}$.

${ }^{20}$ MAHONEY and THELEN, op. cit., note 2, pp. 17-19.

${ }^{21}$ Consolidated Version of the Treaty on European Union, Official Journal of the European Union C 326/13, 2012.

22 TFEU, op. cit., note 5.

23 COUNCIL OF THE EUROPEAN UNION, "Council's Rules of Procedure (2009/937/ EU)", Official Journal of the European Union, L 325 2009, see Articles 7-10.

${ }^{24}$ EUROPEAN PARLIAMENT, Rules of Procedure of the European Parliament, 7th parliamentary term, 2013, see 103-104.

25 http://www.europarl.europa.eu/oeil/home/home.do 
Thirdly, it relies on sixty-seven semi-structured interviews conducted between 2006 and 2012 with members of the Secretariat of the Council, members of the Secretariat of the Commission and representatives of the member states in the Council. The Council of the European Union is divided into ten sectors (Agriculture, Environment, etc.) but the main preparatory committee, the Coreper, is not sectorized and deals with measures across sectors. Members of this Committee were interviewed. In addition, interviews were conducted in three sectors: Environment; Agriculture; and Justice and Home Affairs, because the level of publicity variates across these sectors. Three categories of interviews can be distinguished.

First, fifty-six interviews dealt with decisional practices in the Council. This dataset provides us with information on the effects of increased publicity in the Council. Nine interviews were conducted with members of the Secretariat of the Council, national representatives in the Council or members of the Commission who were active before 1994 (that is, at a time when no information on the activity of the Council was publicly available) and after this date, which means that they witnessed the implementation of the first transparency rules. Fourty-seven interviewees were members of the General Secretariat of the Council, national representatives in the Council or members of the Commission at the time of the interview. Five of them were taking part in the Council negotiations as national representative or EU official even before 1994. Seven of them were active in the Agriculture sector and nine of them in the Environment sector.

Second, the Lisbon Treaty (that came into force in late 2009) having introduced codecision in two sectors, Agriculture, and Justice and Home Affairs, while these two councils once worked entirely behind closed doors, their sessions are now partly public. For this reason, in 2012, five interviews were conducted with members of the Agriculture Council and of the Justice and Home Affairs Council who witnessed this institutional reform.

Lastly, in 2012, six interviews on the evolution of transparency rules and their recent modifications were conducted with persons who were members of the Directorate General-F for "Communication and Transparency" (hereafter, DGF) at the General Secretariat of the Council either at the time of the interview or in the past.

The main hurdle that transparency research has to overcome is methodological: how to compare actors' practices behind closed doors with their practices in public settings? The interviewees were selected in order to make this comparison possible.

Firstly, Council practices prior to 1994 (the year in which the Council started publishing its voting results) were compared with its practices after 1994. The interviewees were: 
- Council members present before and after the implementation of the transparency rules, and therefore able to convey their impressions on the changes brought by transparency;

- Council members who were present either before or after the implementation of the transparency rules, which also made a comparison possible.

- DGF members who contributed to the elaboration of the transparency rules since the beginning of the 1990s.

A second comparison was possible through interviews with members of the Agriculture Council and of the Justice and Home Affairs Council. We interviewed them on the effects of codecision after the Lisbon Treaty, avoiding asking them how publicization of sessions influenced or changed their practices. Thanks to this strategy, it was possible to determine whether the interviewees referred to transparency without being prompted. In those cases in which, approximately forty minutes into the interview, the actors had not referred to transparency, we directly interviewed them on the topic.

One could easily argue that the interview method is unsuited to a research on the Council because diplomats are not keen to talk about their activities and fear to betray the secret contents of negotiations. This criticism is unconvincing for four reasons.

Firstly, the national representatives were rarely interviewed on their positions in specific negotiations. Rather, interviews focused on negotiation practices in general. Apparently, representatives did not expect to be interviewed on this topic, since they are usually interviewed on specific negotiations, which had the advantage of "reassuring" them and perhaps leading them to talk more freely.

Secondly, different types of actors were interviewed in addition to national representatives. Within the Council, legislative proposals are first debated by working groups, then by the Coreper or the SCA, and finally by the Council of Ministers. In addition, when the codecision procedure is legally stipulated, texts are debated in the framework of "informal trialogues" and "conciliation committees". These trialogues and committees include the Council presidency (held by a different member state each semester), a "rapporteur" representing the EP and a representative of the Commission. At each level in the Council (working group, Coreper or SCA, and the Council of Ministers itself), meetings are attended by the presidency, representatives of each member state and a representative of the Commission (the EP is not represented during these meetings). The sample of interviewees included actors holding different posts at all of the different levels. Furthermore, interviewed were conducted with civil servants who had been in their posts for decades and were able to deliver general descriptions of the evolution of practices. 
Thirdly, overlooking the interview method seriously diminishes the possibility of obtaining information on Council activities. Even if published documents are numerous, relying solely on these sources is obviously not a workable strategy for a study of transparency. Furthermore, the legislative process is characterized by several unwritten rules ${ }^{26}$. The interview format alone allows us to identify such rules.

Finally, in order to assess the effects of publicity, we first considered comparing the public Council minutes with minutes of the sessions held before 1994 (a similar method is used by Meade and Stasavage ${ }^{27}$ ). We examined the Council and Coreper minutes for the period prior to 19871992. However, several interviews with members of the Legal Service of the Council Secretariat before 1994 revealed that EU civil servants reported just a small fraction of information in the minutes and that these minutes did not accurately reflect the debates. For this reason, the comparison was not possible prior to 1994. It might be possible if recordings of the Council sessions were available. But in these circumstances, the only adequate method for obtaining information on the practices of Council members before 1994 was the interview method.

\section{Results}

This section assesses the extent to which the increase of transparencypromoting regulations allows citizens to get more information on the positions taken by representatives over the course of the legislative process. First, it accounts for the implementation of the transparency rules in the Council. Then, it analyzes the consequences of codecision on actors' practices and accountability.

\section{The implementation of transparency rules in the Council of the European Union}

\subsection{Publicity of WritTEN DOCUMENTS}

Numerous documents are published on the Council website. However, two hurdles limit the information made available to citizens. Firstly, some documents are categorized as sensitive by the Secretariat and are not made

${ }^{26}$ HELMKE, S. and LEVITSKY, G., "Informal Institutions and Comparative Politics: A Research Agenda", Perspectives on Politics, 2004, Vol. 4, pp. 725-740.

27 MEADE and STASAVAGE, op. cit., note 12. 
available for this reason ${ }^{28}$. Secondly, the content of public documents is insufficient. Existing studies have accounted for the first hurdle. We will focus on the second one.

Most legislative decisions are unofficially taken in the preparatory committees (Coreper and $\mathrm{SCA}^{29}$ ). However, the minutes of their sessions are not published. Since only ministers have the right to vote, they usually publicly ratify measures on which committees have already reached an agreement behind closed doors. When no agreement can be reached at the committee level, the presidency of the committee usually sends the debated measure to the Council of Ministers. However, in such cases, ministers tend to work behind closed doors and the public minutes do not report their debates verbatim. Members of the Secretariat generally avoid publicizing ministers' individual positions, unless asked to do so by the ministers themselves ${ }^{30}$. Therefore, the hurdles to transparency are, apparently, the looseness of the rules, since they do not compel the Secretariat to produce verbatim reports of Council debates; and their incompleteness, since they do not lift the veil on the main decisional stages, that is the Coreper, the SCA and the working groups.

One could argue that publication of the Committees' verbatim minutes would ensure greater information on the positions taken by national representatives. However, the legislative process is based on negotiations. During committee sessions, national representatives tend to formulate ambiguous positions in order to keep some room for maneuver during the negotiation process - and more specifically, in order to extract concessions from the presidency and/or the Commission. Furthermore, the presidency does not systematically ask each delegation its position. It usually asks, "Who has problems with the proposed measure?". In the diplomatic setting of committees, this method tends to deter unsatisfied delegations from taking the floor because they do not want to be seen as marginalized (we analyzed this practice in Novak 2011 ${ }^{31}$ ). Because delegations often stake out ambiguous positions during the plenary sessions, the presidency has to meet with them bilaterally in order to understand their position. Given that negotiations mostly depend on these bilateral meetings, the committee minutes would not offer much information on delegations' real positions or on the reasons why they took them. Simply lifting the veil on committees' activities is not enough to guarantee better information on actors' positions. The decisional practices themselves would have to change.

28 CARVEL, op. cit., note 17; CURTIN, op. cit., note 10.

29 COUNCIL, op. cit., note 23, Article 19.

30 Ibid., Article 13.

31 NOVAK, S., La Prise de Décision au Conseil de l’Union Européenne, Dalloz, Paris, 2011. 
One might object that ministers' positions are made public thanks to two rules. First, when codecision between the Council and the EP is the legally stipulated decision-making procedure, Council debates must be public. Secondly, the vote must also be public ${ }^{32}$. However, these two rules fail to guarantee accurate information on the ministers' positions.

\subsection{Publicity OF SESSIONS}

First of all, legislative debates are usually not debates at all: instead, each minister reads a pre-written text. Ministers tend to state flexible or imprecise positions because they take the floor under the shadow of negotiations that will take place behind closed doors in committees and working-groups. Transparency rules do not allow us to know which positions delegations took in working groups and in committees.

However, this is not the only hurdle to transparency. In the Agriculture Council, which meets more often and legislates more than other sectoral councils, a higher proportion of decisions are made directly by ministers. But even when sessions are public, ministers avoid the gaze of the cameras in order to establish compromises. A representative at the Agriculture Council notes:

We don't know the real reasons behind compromises. It is unimaginable that this type of decision making could be done in front of the camera. You do go around the table in public, but you don't say everything. And then there are the trilateral and bilateral talks, and so you keep ministers locked in for the entire night - this is the conclave method. There is no interest in making this public because (...) it will necessitate seeking compromises even as the reasons behind them aren't rational. These things depend on the circumstances. Everyone must abandon their original convictions. (October 2012).

For instance, on September 23, 2013, the Agriculture Council held a public session on reforming the Common Agricultural Policy. The presidency interrupted the session for a lunch break. After the break, it reopened the public session and stated that the ministers had reached a compromise through informal exchanges. The presidency summed up the compromise without indicating which delegations received concessions and which delegations gave up some demands.

According to interviews conducted in 2007 and 2008, members of the Agriculture Council and of the Justice and Home Affairs Council dreaded the effects of increased openness of plenary sessions after the Lisbon Treaty.

32 Article 16.8 TEU. 
Their main argument was that publicity diminishes the efficiency of the legislative process, even if, to our knowledge, said theorem has not yet been proven. However, according to several interviews conducted after the transparency reform, "transparency has not changed anything". A member of the Secretariat even compared the public sessions to the "Potemkin villages" (November 2012). Interestingly, interviews with persons who were at the Council in 1993-1994 revealed the same sequence: anxiety prior to the disclosure of the votes was followed by the claim that publicity actually "did not change anything". This phenomenon is not particularly surprising given that negotiations still take place behind closed doors.

\subsection{Publication of Votes}

Since 1994, Council votes have been made public. The publicity of votes is a notably ambitious transparency rule since prior to it, no information on the Council sessions had been made public. Since 2006, when the Council codecides with the EP, votes must be broadcast on the Internet.

The publication of votes has had a positive impact on actors' accountability in two contexts. Firstly, it has put an end to the "silent qualified majority" practice. Before 1994, when the presidency wanted to pass a measure in spite of a blocking minority, it sometimes asked the permanent representatives who had received the instruction to oppose it to remain silent. The presidency would then orally note the qualified majority without opening a voting procedure. After that, representatives who would have voted against the measure would inform their government that they had been defeated without reporting the existence of other opponents of the measure. The publication of votes prevents this kind of strategy since it makes the existence of a blocking minority obvious (for more details on this practice, see Novak $2011^{33}$ ).

Furthermore, when national parliaments exercise control over their ministers' votes, the publication of votes ensures their accountability, to some extent. However, tight parliamentary control is in force in only a few member states of the $\mathrm{EU}^{34}$. In Denmark, if a majority of Members of Parliament oppose an adopted measure, the minister will have to be loyal to her parliament and publicly vote against the measure. However, given that control by national parliaments is not well developed in the EU, nothing can prevent deals between national representatives in preparatory committees. A minister might publicly oppose an adopted measure while supporting it

${ }^{33}$ NOVAK, S., op. cit., note 31.

${ }^{34}$ HAYES-RENSHAW, F., VAN AKEN, W. and WALLACE, H., "When and why the EU Council of Ministers votes explicitly", Journal of Common Market Studies 2006, Vol. 44, No. 1, pp. 161-194. 
behind closed doors. Presumably, then, publication of votes increases the accountability in the Council only if national parliaments of each member state can exert control over their ministers' voting behaviour.

Several hurdles limit the effectiveness of the publication of votes.

Firstly, voting results are published only if a measure is adopted. We do not have any data on the rejected acts ${ }^{35}$, even though neither the Treaty nor the Council Rules of Procedure specify that votes on rejected acts should not be published. And only insiders are aware of the fact that votes on rejected acts are not published. One could argue that such votes are not published because when the presidency deems that a measure is not supported by enough participants, it does not ask the delegations to vote. However, we accessed internal reports of the European Commission showing that in a few cases, a blocking minority did vote against a measure. There were only four or five cases per year, but by opting not to publishing these votes, the Council actually infringed the rule.

Secondly, voting results are published even if in practice, the presidency rarely opens voting procedures. The presidency and the Secretariat usually collect the voting intentions of the member states through bilateral talks with the different delegations. On the basis of these bilateral exchanges, during committee sessions, the presidency orally notes that a qualified majority has been reached and that a measure can be adopted ${ }^{36}$.

According to the Treaty (article 16.8), "The Council shall meet in public when it deliberates and votes on a draft legislative act." But according to the Treaty Council's rules of procedure (article 9), "the results of votes (...) shall be made public". This interpretation of the Treaty, substituting the "results of the vote" for the "vote" itself, has immense consequences in terms of transparency. For one thing, it allows Council members to keep acting as they did when votes were not published: individual countries do not have their votes announced, the chair just says a majority has been reached. Furthermore, the Council Secretariat has to face a contradictory situation: most decisions are made behind closed doors by national representatives who do not vote explicitly, even while votes must be public. Before the Council session during which a given measure has to be adopted, the Secretariat calls on the different permanent representations so as to learn of their positions and prepares a voting sheet. During the public Council sessions, these voting results are displayed on a big screen while the Presidency states that the measure shall be adopted.

35 Ibid.

36 CURTIN, D., "Democracy, Transparency and Political Partipation: Some Progress Post-Amsterdam", in DECKMYN, V. and THOMSON, I., Openness and Transparency in the European Union, EIPA, Maastricht, 1998, p. 116; NOVAK, S., op. cit., note 31. 
The first problem raised by this practice is the following: anyone who reads the Treaty without being aware of the Council's practices would think that the ministers vote by raising hands or by roll-call. The second problem is that public votes do not necessarily reflect the positions taken by national representatives behind closed doors. According to an unwritten rule, when the presidency of the Coreper or of the SCA has already stated that a measure can be adopted, ministers cannot decide to oppose if they have not previously informed the presidency during negotiations. This unwritten rule aims to avoid the situation of a public session in which a measure is unexpectedly rejected before ministers who have come to Brussels expressly to adopt that measure. In this context, ministers tend to join the qualified majority when they see that they cannot block a measure anymore. Except for the few member states in which ministers receive strict parliamentary mandates, the general tendency is to join the qualified majority even if one is not satisfied with a measure ${ }^{37}$. A representative at the Agriculture Council sums up this habit: "It's difficult for minister to vote against [a measure] or abstain because they don't like to be marginalized" (October 2012).

The publication of votes does not allow citizens to monitor their representatives' positions because of the conjunction of an organizational feature (votes are registered after the announcement of a qualified majority behind closed doors) and of a lack of control by the national parliaments over their representatives. To guarantee accountability, the publication of votes necessitates a complementary rule: each national parliament should monitor its ministers' votes.

\section{The codecision}

Against this account, one might object that the EP's growing participation has increased the transparency of the EU legislative process. Both plenary and committee sessions take place in public. However, several recent studies of the codecision show that legislative actors have developed practices that stimulate the efficiency of the decisional process at the expense of transparency ${ }^{38}$. While the extension of codecision was supposed to increase the democratic legitimacy of decisions, it has triggered the following paradox: although the EP has campaigned for increased transparency within the Council, the Members of the EP have actually adopted the diplomatic habits

37 NOVAK, S., op. cit., note 31.

${ }^{38}$ HUBER and SHACKLETON, op. cit., note 13; BURNS, C., RASMUSSEN, A. and REH, C., "Twenty Years of Legislative Codecision in the European Union. Special Issue", Journal of European Public Policy, 2013, Vol. 20, No.7. 
and negotiating practices of the Council, which has blurred distinctions between the positions of the different actors ${ }^{39}$. Existing studies of the codecision have shown that the procedure has failed to reduce the democratic deficit, although to our knowledge, they have not put forward this paradox.

Statistics show that the EP and the Council pass a growing proportion of measures by means of "early agreements": in order to accelerate the legislative process, representatives of each institution involved in the legislative process (Commission, EP and Council) meet in the framework of "informal trialogues" and negotiate until they reach a compromise. Hence, the Council's notorious habit of seeking consensus has spread to the entire legislative process, while this method obscures different actors' positions and deters the minority from voicing its disagreement $t^{40}$.

Interviews have revealed a third cause of opacity. In principle, the EP represents the citizens and is organized along ideological lines while in the Council, the interests of the member states are defended by their permanent representatives and ministers. However, members of Permanent Representations of member states sometimes approach their co-national members of the EP and attempt to convince them to introduce amendments corresponding to the position defended by their country in the Council. This strategy is, of course, more profitable in the cases of big member states, since they are represented by higher numbers of members of the EP. Strangely enough, this practice did not seem to shock interviewees, even though it conflicts with the principle of representation laid out in the Treaty and renders the legislative process even more opaque.

\section{Discussion}

The empirical investigation reveals a partial failure of transparency rules, partly due to the fact that no external actor systematically controls their enforcement. This section discusses the organized-hypocrisy theory and the realist conventional wisdom. It argues that they do not fully account for the effects of the transparency rules because they underestimate the complexity of the implementation of rules. The legislatve actors implement the rules but they exploit their ambiguities and convert them to their own benefit.

39 HUBER and SHACKLETON, op. cit., note 13, p. 1041.

40 NOVAK, S., op. cit., note 31; BURNS, C., "Consensus and Compromise Become Ordinary - But At What Cost? A Critical Analysis of the Impact of the Changing Norms of Codecision Upon European Parliament Committees", Journal of European Public Policy, 2013, Vol. 20, No. 7, pp. 988-1005. 


\section{The limits of the realist common wisdom}

The thesis according to which publicity leads actors to withdraw behind closed doors is borne out in only two situations. Firstly, because the Council minutes are public, the Secretariat avoids reporting member states' positions in the minutes (interviews Council Secretariat, October 2013). Secondly, in the few cases where a measure is rejected by the Council, voting results are not made public.

However, although the main stages of the decision process take place behind closed doors (in working groups, the Coreper and the SCA, informal trialogues and conciliation committees), they are not subject to any transparency obligation. For this reason, the fact that the actors negotiate behind closed doors is not actually an effect of publicity but a standard operating procedure. It might be objected that in the Agriculture Council, which meets in public, ministers establish compromises in non-public settings. However, such behaviour is not triggered by the fact of sessions' increased openness. Ministers establish compromises in non-public settings because the search for compromise is based on bilateral and trilateral negotiations between the different national delegations and the presidency and/or the Commission. Even when the Agriculture Council worked entirely behind closed doors (i.e., before the implementation of the Lisbon Treaty), actors already used to work in smaller groups and avoided negotiating in the framework of plenary sessions. The failure of transparency is not due to the fact that actors evade transparency rules, but to the fact that the decision process relies on negotiations aimed at compromises. One can define this decision method as an exchange of credible threats and promises ${ }^{41}$ based on an asymmetry of information, on the ambiguity of negotiatiors' positions and on pure bluffing.

One might argue that actors do evade the rule according to which votes must be made public ${ }^{42}$. The presidency does not open voting procedures during public sessions. Instead, it collects the votes before public sessions are held, without asking delegations to vote openly, even behind closed doors. During the public sessions, the results of votes are made public but the vote itself is not public. More than evading the rule, actors "convert" the rule ${ }^{43}$. Actors consider that publicly voting against adopted measures is a strategic mistake overall because journalists usually pay more attention to public opposition than to consensual behaviour and tend to interpret

${ }^{41}$ ELSTER, J., Deliberative Democracy, Cambridge University Press, New York, 1998, p. 6.

${ }^{42}$ Article 16.8 TEU.

43 MAHONEY and THELEN, op. cit., note 2, p. 18. 
negative votes as failures ${ }^{44}$. This is why ministers tend to publicly oppose adopted measures in order to send a signal at home ${ }^{45}$ only when they expect greater domestic benefits from public opposition than costs.

Actors are likely to convert rules when they have weak veto possibilities while still enjoying a high level of discretion in the enforcement of rules ${ }^{46}$. In the Council of the EU, these two conditions are met: actors cannot prevent the implementation of the transparency rules, but there is no guardian who would impose a strict implementation of said rules, since the Council is an intergovernmental organization most of whose members are not systematically controlled by national parliaments.

\section{Publicity as a Potemkin Village? A critique of the organized-hypocrisy theory}

At first sight, the disconnection between the official transparency norms and the actors' practices seem to be a case of organized hypocrisy. According to Brunsson, when institutional norms fail to correspond to those demanded in order to obtain efficient action, it can be expected that organizations, insofar as efficiency is important, will enact two systems, procedures and ideologies-one for coordinating actions and the other for its external image. These different arrangements should not conflict; they should be mutually independent and separated.

Actually, the Treaty refers to the tension between transparency and efficiency and our interviewees often claimed that secrecy is necessary to efficient negotiations. Some descriptions also seemed to imply a decoupling between transparency rules and decisional practices. To what extent can transparency of the EU legislative process be considered as a situation of organized hypocrisy?

On the one hand, since the beginning of the 1990s, the development of regulations and speeches on transparency-what could constitute the "external image" of the legislative process in Brunsson's words - has been impressive. One department of the Council Secretariat, the Directorate General-F, is explicitly in charge of "communication and transparency" and the pages of the Council's website devoted to transparency have expanded over the years. Moreover, a "Transparency Register" was launched in 2012

${ }^{44}$ NOVAK, S., "The Silence of Ministers: Consensus and Blame Avoidance in the Council of the European Union", Journal of Common Market Studies, 2013, Vol. 51, pp. 1091-1107.

45 HAYES-RENSHAW et al., op. cit., note 34.

${ }^{46}$ MAHONEY and THELEN, op. cit., note 2, p. 19. 
by the Commission and the EP, to which interest groups can register if they wish to do so.

On the other hand, when one looks at actors' actual practices, they seem to be decoupled from this norm of transparency for several reasons. First of all, documents published on the Council website offer information on Council sessions but not on debates in the working groups and preparatory committees even if these debates arguably accomplish the bulk of legislative work - a situation of which drafters of the transparency rules are unavoidably aware. Moreover, the Council "minutes" do not report sessions verbatim and do not mention member states' positions. Finally, the empowerment of the EP, supposed to increase transparency in the decisional process, has resulted in increased opacity of actors' positions, since measures are negotiated behind closed doors by representatives of the EP, the Council and the Commission.

Most Council members strongly believe that acting behind closed doors is necessary to ensure an efficient process. This belief collides with the fact that institutions are constrained such that displays of transparency are necessary in order to increase their legitimacy. In this context, transparency rules tend to be decoupled from actors' practices. By way of a defence during the Carvel case, the Council publicly declared:

The Council normally works through a process of negotiation and compromise, in the course of which its members freely express their national preoccupation and positions. If agreement is to be reached, they will frequently be called upon to move from those positions, perhaps to the extent of abandoning their national instructions on a particular point or points. This process, vital to the adoption of Community legislation, would be compromised if delegations were constantly mindful of the fact that the positions they were taking, as recorded in Council minutes, could at any time be made public through the granting of access to these documents, independently of a positive Council decision ${ }^{47}$.

In a recent study, Laursen shows that the Council's philosophy has not changed in this respect: Council press officers claim that they cannot deliver detailed information on the positions of the member states in preparatory committees because it might weaken the presidency when it negotiates with a third party or another institution such as the $\mathrm{EP}^{48}$. In addition, Council members generally assume that journalists are attracted by conflictual situations, which they report more easily than consensual situation. For

47 Statement of Defence of the Council of the European Union in Case T. 194/94, Bxl, 13 July 1994, quoted by STASAVAGE, D., op. cit., note 13, p. 14; see also CURTIN, D., op. cit., note 36 , p. 116.

48 EUROPEAN PARLIAMENT, op. cit., note 24, p. 9. 
this reason, press officers are instructed not to reveal the positions of the member states in the committees ${ }^{49}$.

In this context, one could argue that publicization of some parts of Council sessions and of EP sessions and committees combined with the possibility of working behind closed doors in preparatory committees, informal trialogues and conciliation committees, allow actors to comply with both transparency norms and the imperative of efficient action.

However, the organized-hypocrisy interpretation should be qualified because it relies on a condition that the case of the EU legislative process does not meet: organized hypocrisy involves the absence of interaction between an organization's "external image" (the transparency norm in the present case) and its acts and decisions. But this parallellism amounts to underestimating the inherent complexity of implementing rules: even when actors seem to ignore rules, it does not mean that the existence of rules has no influence on their actions, nor does it mean that actors will not interpret and implement the rules in a way that is beneficial to them. In the case of the EU legislative process, the increased publicity of sessions has had an influence on the decisional process itself.

On the one hand, the publication of votes put an end to some practices that were incompatible with accountability (see 3.1.3). On the other hand, actors sometimes make strategic use of transparency rules over the course of negotiations. In some cases, actors tend to convert transparency rules as they use publicity to put pressure on their opponents. For instance, in order to speed up negotiations over the Climate Change Package, the Commission encouraged the French presidency to push debates onto the public stage (interview November 2007). According to several members of the Environment Council, the presidency uses publicity as an asset because ministers are reluctant to publicly oppose measures widely considered progressive.

National representatives also sometimes adopt this strategy. For instance, in 2011-2012, the Council and the EP debated a reform of the Most Deprived Persons Programme. This programme allowed for the redistribution of agricultural surpluses to food banks. When this programme was first designed, European agriculture was still producing surpluses but as overproduction ended, the programme began to be funded by the Common Agricultural Policy (CAP) budget. The German government asked for a reform of this programme on the grounds that its original rationale was now distorted. Several member states allied with Germany and built a blocking coalition. The French government, on the hand, asked for an extension of

49 Ibid., p. 10. 
this programme because the French food bank had worked out a yearly plan assuming reliance on the CAP budget. This issue became a hot topic in France and the reform unpopular. After lengthy discussion with the German minister, the French minister convinced her not to oppose the extension of this programme. Apparently, among other strategic weapons, French negotiators used the fact that Germany was publicly seen as indifferent to the cause of the most deprived persons to convince the German minister to agree to extend the programme (interviews, October 2012).

Interviews allowed us to collect several cases in which actors strategically exploit publicity. Because of space limits, it is not possible to report all these cases, but they nonetheless offer interesting opportunities for future more indepth case studies. Overall, these cases tend to show that a clean disconnect between official norms and practices is not likely to often occur Brunsson's claim notwithstanding ${ }^{50}$. The concept of "conversion" allows us to account for the effects of transparency rules in a richer and more nuanced way. Even if actors seem to evade or ignore rules adopted to increase the public legitimacy of their organization because they deem them incompatible with efficient action, such rules are likely to act at least as "shadows" on actors' practices.

\section{Conclusion}

The empirical investigation shows how complex the implementation of transparency is and how diverse and unexpected its effects are. In spite of the promotion of transparency in EU institutions, the legislative process remains opaque because actors enjoy a high level of discretion as to the implementation of transparency rules and because the crucial stages of the process are not subject to transparency rules. Still, it is inaccurate to argue that the actors merely evade or ignore the transparency rules. One could assume that official transparency in EU institutions acts much as do human rights conventions, analysed by Hafner-Burton and Tsutsui ${ }^{51}$. According to Hafner, after signing such conventions, governments can cover themselves and violate human rights because no external mechanism ensures the enforcement of these conventions ${ }^{52}$. Mutatis mutandis, transparency rules could be considered as a form of window-dressing, the official transparency of the legislative process providing the actors with more freedom to act

50 BRUNSSON, H., op. cit., note 18, xiii.

${ }^{51}$ HAFNER-BURTON, E.M. and TSUTSUI, K., "Human Rights in a Globalizing World: The Paradox of Empty Promises", American Journal of Sociology, 2005, Vol. 110, No. 5, pp. 1373-1411.

52 Ibid., p. 1402. 
than the absence of official transparency, which unavoidably gives rise to suspicion. However, such interpretations of transparency rules, the realist conventional wisdom and the organized-hypocrisy theory - which, in a way, all amount to claiming that transparency "does not change anything" and that public sessions and documents are "Potemkin villages"- are inaccurate in the case of the EU legislative process. The concept of "conversion" 53 offers a fuller and more nuanced explanation of the effects of the transparency rules. In terms of accountability, the problem is obvious: except for the few cases in which transparency ensures the accountability of the actors, transparency does not guarantee more or better information on the positions of actors and is, on the contrary, exploited by those same actors. Transparency rules would increase accountability only if an external actor (such as national parliaments) effectively monitored their enforcement.

However, the analysis of decisional practices also indicates that such control is not a panacea. Transparency rules generally rely on the assumption that behind closed doors, actors openly state their positions during plenary sessions and that decisions are made on this basis. But negotiations in the Council and between different institutional actors (Commission, EP and Council) are mostly based on bilateral and trilateral exchanges. Actors themselves are not fully informed of participants' positions because negotiations imply ambiguity and asymmetrical information. In this context, one can wonder how realistic is the demand for more transparency in the EU legislative process: does requiring transparency in negotiations amount to a fruitless attempt to square the circle? This paper shows that to improve the accountability of the EU legislative process, one must change actors' practices rather than reforming the transparency rules. The ensuing questions are the extent to which one can really expect this to happen, and the problematic tension between transparency and efficiency in decisions.

\section{Bibliography}

BEST, E., "Transparency and European Governance: Clearly not a Simple Matter", in DECKMYN, V., Increasing Transparency in the European Union?, EIPA, Maastricht, 2002, pp. 91-117.

BJURULF, B. and ELGSTRÖM, O., "Negotiating Transparency: The Role of Institutions", Journal of Common Market Studies, Vol. 42, No. 2, 2004, pp. 249-269.

BRUNMAYR, H., "The Council's Policy on Transparency", in DECKMYN, V. and THOMSON, I., Openness and Transparency in the European Union, EIPA, Maastricht, 1998, pp. 69-73.

53 MAHONEY and THELEN, op. cit., note 2. 
BRUNSSON, N., The Organization of Hypocrisy: Talks, Decisions and Actions in Organizations ( $2^{\text {nd }}$ Ed.), Copenhagen Business School Press, Copenhagen, 2006.

BUKOVANSKY, M., "Institutionalized Hypocrisy and the Politics of Agricultural Trade", in ABDELAL, R. and ITHACA, A., Constructing the International Economy, Cornell University Press, 2010.

BURNS, C., "Consensus and Compromise Become Ordinary - But At What Cost? A Critical Analysis of the Impact of the Changing Norms of Codecision Upon European Parliament Committees", Journal of European Public Policy, 2013, Vol. 20, No. 7, pp. 988-1005.

BURNS, C., RASMUSSEN, A. and REH, C., "Twenty Years of Legislative Codecision in the European Union. Special Issue", Journal of European Public Policy, 2013, Vol. 20, No.7.

CARVEL, J., "Request for Documents of the Council: An Account of the Guardian Case", in DECKMYN, V. and THOMSON, I., Openness and Transparency in the European Union, EIPA, Maastricht, 1998, pp. 53-67.

COUNCIL OF THE EUROPEAN UNION, "Council's Rules of Procedure (2009/937/EU)", Official Journal of the European Union, L 325 2009, p. 35.

CURTIN, D., "Democracy, Transparency and Political Partipation: Some Progress Post-Amsterdam", in DECKMYN, V. and THOMSON, I., Openness and Transparency in the European Union, EIPA, Maastricht, 1998, pp. 107-119.

CURTIN, D., "Transparency, Audiences and the Evolving Role of the EU Council of Ministers", in FOSSUM, J.E. and. SCHLESINGER, P.R., The European Union and the Public Sphere. A communicative space in the making, Routledge, 2007, pp. 246-258.

CURTIN, D., "Top Secret Europe”, Inaugural Lecture, University of Amsterdam, 2011.

CURTIN, D. and MEIJER, A., "Does transparency strengthen legitimacy?", Information polity 2006, Vol. 11, No. 2, pp. 109-122.

DAVIS, J., "Access to and Transmission of Information: Position of the Media", in DECKMYN, V. and THOMSON, I., Openness and Transparency in the European Union, EIPA, Maastricht, 1998, pp. 121-126.

DECKMYN, V. and THOMSON, I., Openness and Transparency in the European Union, EIPA, Maastricht, 1998.

DECKMYN, V. (Ed.), Increasing Transparency in the European Union? EIPA, Maastricht, 2002.

DE LEEUW, M.E., "Openness in the Legislative Process in the European Union", European Law Review, 2007, Vol. 32, No. 3, pp. 295-318.

ELSTER, J., Deliberative Democracy, Cambridge University Press, New York, 1998.

EUROPEAN PARLIAMENT, Rules of Procedure of the European Parliament 7th parliamentary term, 2013.

GOSSERIES, A., "Transparency and Democracy", Swiss Political Science Review, 2006, Vol. 12, No.3, pp. 83-90.

HAFNER-BURTON, E.M. and TSUTSUI, K., "Human Rights in a Globalizing World: The Paradox of Empty Promises", American Journal of Sociology, 2005, Vol. 110, No. 5, pp. 1373-1411. 
HAYES-RENSHAW, F., "The Council of Ministers", in PETERSON, J. and SHACKLETON, M., The Institutions of the European Union, Oxford University Press, Oxford, 2012, pp. 68-95.

HAYES-RENSHAW, F., VAN AKEN, W. and WALLACE, H., "When and why the EU Council of Ministers votes explicitly", Journal of Common Market Studies 2006, Vol. 44, No. 1, pp. 161-194.

HELMKE, S. and LEVITSKY, G., "Informal Institutions and Comparative Politics: A Research Agenda", Perspectives on Politics, 2004, Vol. 4, pp. 725-740.

HILLEBRANDT, M. Z., CURTIN, D. and MEIJER, A., "Transparency in the EU Council of Ministers: An Institutional Analysis", European Law Journal, 2014, Vol. 20, No.1, pp.1-20

HOOD, C., "Accountability and Transparency: Siamese Twins, Matching Parts, Awkward Couple?", West European Politics, 2010, Vol. 33, No. 5, pp. 989-1009.

HUBER, K. and SHACKLETON, M., "Codecision: A Practitioner's View From Inside the Parliament”, Journal of European Public Policy, 2013, Vol. 20, No. 7, pp. 1040-1055.

KRASNER, S.D., Sovereignty: organized hypocrisy, Princeton University Press, Princeton, 1999.

LAURSEN, B., "Transparency in the Council of the European Union: Why journalists don't get the full picture", Journalism, 2012, Vol. 14, No. 6, pp. 771-789.

LIPSON, M., "Peacekeeping: Organized Hypocrisy?", European Journal of International Relations, 2007, Vol. 13, No. 1, pp. 5-34.

MAHONEY, J. and THELEN, K. (Eds.), Explaining Institutional Change: Ambiguity, Agency, and Power, Cambridge University Press, New York, 2010.

MEADE, E. and STASAVAGE, D., "Two Effects of Transparency on the Quality of Deliberation", Swiss Political Science Review 2006, Vol. 12, No. 3, pp. 123-133.

MEIJER, A., "Understanding the Complex Dynamics of Transparency", Public Administration Review, 2013, Vol. 73, No. 3, pp. 429-439.

MEYER, J.W. and ROWAN, B., "Institutionalized Organizations: Formal Structure As Myth and Ceremony", American Journal of Sociology, 1977, Vol. 83, pp. 340-363.

NAURIN, D., "Transparency, Publicity, Accountability - The missing links", Swiss Political Science Review, 2006, Vol. 12, No. 3, pp. 90-98.

NAURIN, D., Deliberation Behind Closed Doors: Transparency and Lobbying in the European Union, ECPR Press, Colchester, 2007.

NOVAK, S., La Prise de Décision au Conseil de l'Union Européenne, Dalloz, Paris, 2011.

NOVAK, S., "The Silence of Ministers: Consensus and Blame Avoidance in the Council of the European Union", Journal of Common Market Studies, 2013, Vol. 51, pp. 1091-1107.

COUNCIL OF THE EUROPEAN UNION, Regulation (EC) n. ${ }^{\circ} 1049 / 2001$ of the European Parliament and of the Council of 30 May 2001 Regarding Public Access to European Parliament, Council and Commission Documents. Official Journal of the European Communities. L 145/43.

STASAVAGE, D., "Does Transparency Make a Difference? The Example of the European Council of Ministers". Working Paper. London School of Economics, 
2005, available at: http://as.nyu.edu/docs/IO/5395/transparency.pdf (last accessed: 1 April 2014).

TAN, Y., «Transparency Without Democracy: The Unexpected Effects of China's Environmental Disclosure Policy», Governance, 2014, Vol. 27, No. 1, pp. 37-62.

WEAVER, C., Hypocrisy Trap: The World Bank and the Poverty of Reform, Princeton University Press, Princeton, 2008.

WESTLAKE, M., "Maastricht, Edinburgh, Amsterdam: The 'End of the Beginning", in DECKMYN, V. and THOMSON, I., Openness and Transparency in the European Union, EIPA, Maastricht, 1998, pp. 127-145. 